The Turkish Online Journal of Design, Art and Communication - TOJDAC October 2017 Volume 7 Issue 4

\title{
AN INVESTIGATION THROUGH CONTENT ANALYSIS IN INFOGRAPHICS
}

\author{
Hüseyin UZUNBOYLU \\ Near East University Faculty of Education, North Cyprus \\ huseyin.uzunboylu@neu.edu.tr \\ Mobina BEHESHTI \\ Near East University Faculty of Education, North Cyprus \\ mobina.beheshti@neu.edu.tr
}

\begin{abstract}
The aim of this study is to investigate studies and trends in infographics in order to determine the specifications of its scientific content. The study analyzes 161 theoretical and experimental research papers published between 2006 and 2016 through the utilization of both qualitative and quantitative indicators. Citation analysis is used in this research in order to examine studies related to infographics that are indexed in scientific journals. Infographics and data visualization related keywords are jointly used in the search for documents. As a result of this research, it can be seen that the number of citations and the number of research papers significantly increased in 2016 and also the result allows the researchers to specify the attributes of the contents of the scientific journals. In future research, it is recommended that the citation analysis method is combined with other types of analysis.
\end{abstract}

Keywords: Bibliometric; Content analysis; Scopus; Infographics

\section{İNFOGRAFIK ÜZERİNE BİR İÇERİK ANALIZİ ARAŞTIRMASI}

$\ddot{\mathbf{O} z}$

$\mathrm{Bu}$ çalışmanın amacı infografik araştırmalarındaki eğilimlerin içerik analizi çerçevesinde belirlenmesidir. Bu çalışmada, 2006 ve 2016 yılları arasında nicel ve nitel yöntemler kullanılarak yapılmış teorik ve deneysel araştırma 161 makale incelenmiştir. Bu araştırmada bilimsel uluslararası SCOPUS indeksinde taranan dergilerde yayınlanan infografik ile ilgili çalışmaları incelemek için içerik analizi kullanılmıştır. Makaleler taranırken "inforgrafik" ve "veri görselleştirme" anahtar kelimeleri kullanılmıştır. Araştırma sonucunda, makalelerdeki alıntı sayısı ve makale sayısının 2016 yılında önemli bir artış gösterdiği belirlenmiştir. $\mathrm{Bu}$ araştırma ile bilimsel dergilerdeki infografik araştırmalarının özellikleri elde edilmiştir. İleriki araştırmaların farklı analiz türleri ile içerik analizi yöntemi birleştirilerek infografik araştırmalarının eğilimlerinin incelenmesi önerilmektedir.

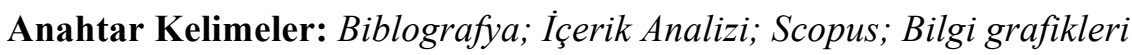

Submit Date: 13.06.2017, Acceptance Date: 16.09.2017, DOI NO: 10.7456/10704100/011 
The Turkish Online Journal of Design, Art and Communication - TOJDAC October 2017 Volume 7 Issue 4

\section{INTRODUCTION}

One of the oldest and most significant branches of bibliometric research is citation analysis, as specified by Eugene Garfield (Mahapatra, 2000). Citation is concerned with referring to other sources containing published studies. Referring means indicating the proper context and providing a clear biographic statement in a reference list. Moreover, Diadato (1994) stated that citation is an extended ranging field of bibliometrics that studies the citations from/to papers.

Citation analysis research papers have been conducted in many fields and have been published in many academic journals, including educational science, geography, medicine, psychology, business, etc. For instance, in psychology, studies were reviewed and published in the journal of American Psychological Association (APA) by Smith et al. (1998), and Howard, Cole and Maxwell (1987). Therefore, older research papers will obtain citations/are cited by newer studies (Rousseau, 2008).

Furthermore, other scientists have investigated studies from numerous science education journals. The researchers tried to find the documents that obtained the most citations in the Journal of Pediatric Psychology for the period 1976-2006, by analyzing 100 published papers; however, in the literature, there was no information regarding infographics. Majority of the published studies were discussed and the trends and patterns were identified in educational technology (eg, Angling \& Towers, 1992; Klein, 1997; Maushak, Price \&Wang, 2000; Ely, 2002; Gall, Ku, Gurney, Tseng \& Yeh, 2004; Reiser \& Dempsey, 2007; Hew \& Kale, 2007; Aylward, Roberts, Colombo and Steele, 2008; Hursen \& Ozcinar, 2008). The high number of studies on educational technology might be due to increased requirement in being competent in terms of technological knowledge and skills (Ozdamli \& Tavukcu, 2016) and increased use of interactive technologies such as ipad and social media in education (Dhir, Gahwaji \& Nyman, 2013; Bicen, 2015). Uzunboylu and Karagozlu (2015) reviewed the studies on flipped classroom and provided information about the effectiveness of flipped classroom in education and Bagriyanik and Karahoca (2016) conducted a systematic literature review on big data in software engineering. In addition, Cetin (2015) reviewed the master and doctorate thesis related with computer education and instructional technologies published in Turkey Higher Education Council and revealed the general trends in the published thesis. When the literature is examined, it is seen that the number of studies reviewing the studies on arts, design, graphic or infographics is limited. Furthermore, Allahverdiyev and Yucesoy (2017) provided a review on glass art from past to present from the perspective of arts.

For instance, in the field of weather forecasting and climate investigation, Beuker and Boerstra conducted research in order to investigate the results of climate change by using infographics and consequently published their paper in the International Conference on Healthy Buildings (Beuker \& Boerstra, 2012). In addition, Tuncali (2016) focused on how infographics is used in environmental issues such as creating environmental awareness. Schwabish and Jonathan (2012),Claes and Moere (2013), Tocque and Kennedy (2013), and Alabdulqader (2013) conducted studies into social sciences, behaviorism and ethics by visualizing information regarding these areas as infographics (Schwabish \& Jonathan (2012); Tocque \& Kennedy (2013); Claes \& Moere (2013).

These studies attempted to use infographics in order to deliver valuable information and to improve the learners as well as the society's knowledge regarding their society, behavioral sciences and computer ethics. In particular, all the studies published between 20062016 appeared to periodically identify and discuss the trends in data visualization in instructional technology comprising Mathematics, Engineering, Computer Science, Arts and Humanities, Medicine, Business, and Management and Accounting.

Submit Date: 13.06.2017, Acceptance Date: 16.09.2017, DOI NO: 10.7456/10704100/011

Copyright $($ The Turkish Online Journal of Design, Art and Communication 


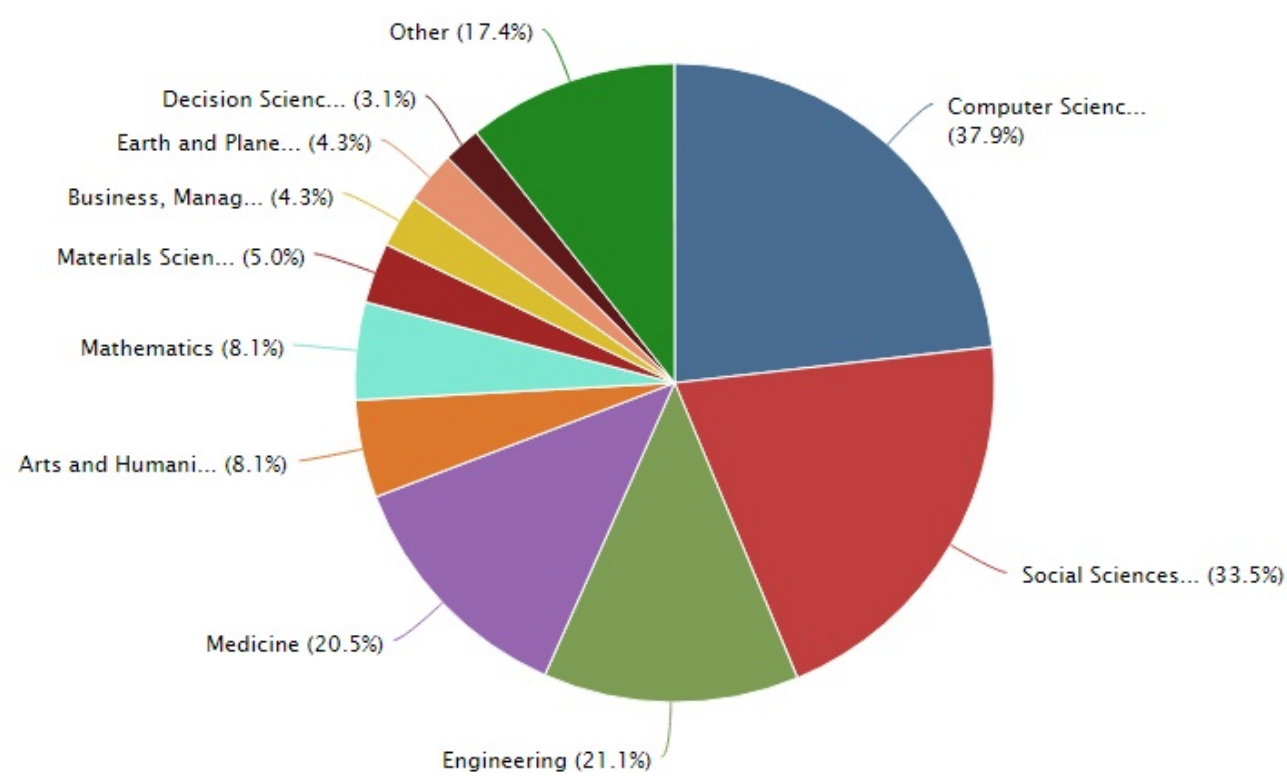

Figure 1: Subject area of research papers

As shown in Figure 1 many studies have been conducted on the subject of infographics or data visualization methods in the referred academic journals containing business and technical communication, health behavior, media and society, computer science, instructional technology, weather forecasting, computer graphics, and marketing. Therefore, it is observed that, infographics has become a field of educational technology. Furthermore, all the studies analyzed were created through the utilization of document based citation analysis rather than journal content analysis, as had previously been the case Citation analysis utilization began in the 1950s with Garfield (1955), who proposed the method of citation indexing. These citations comprise the Science Citation Index-Expanded (SCIE), Arts, Humanities Citation Index (AHCI), Social Sciences Citation Index (SSCI), and the Institute for Scientific Information (now Thomson Reuters), so the methodological analysis was initiated through research trends and the effectiveness of scholarly works.

Furthermore, citation analysis is utilized in the social sciences in order to examine the research assistance of professional journals, organizations and individuals (Brown \& Gardner, 1985). Additionally, citation analysis is not only a practical method used to specify documents in a given journal with a major number of citations, but can also show the effect of research papers on any field (Aylward et al., 2008). Moreover, citation analysis enables researchers to investigate how frequently a study has been cited by other scientists or how effective the study is?

The present study incorporates citation analysis on infographics in order to characterize the specifications of the scientific content. The study analyzes 161 theoretical and experimental research papers published during the period 2006-2016, by utilization of both qualitative indicator (subject area, author, language of publication and university of origin) and quantitative indicators (citation of article, authorship index). Citation analysis is performed on information obtained via the Scopus database. The study results will enable the researchers to specify the attributes of the content of the scientific journals. 


\section{METHODOLOGY}

In this research, the Scopus database is utilized. This database is one of the largest databases in the world that contains citations and abstracts in both peer-reviewed literature and web source quality (Ramesh \& Nagaraju, 2000). The present research is limited to 161 articles and conference papers that are related to the fields of infographics, using the keywords 'infographics' and 'data visualization' in order to search for published documents during the period between 2006 and 2016; furthermore, the papers were required to have received a minimum of 400 and a maximum of 85,000 citations in the last 10 years. The gathered data derived from the Scopus citation database have been evaluated and illustrated in the form of figures and tables.

Additionally, the specified papers were examined based on the document type, language, sources of the document, publication year, and citation by year, number of authors, author's country, and the documents that had gained the most citations. Both keywords were classified and gathered from each document in the period 2006-2016.

Moreover, the keywords can be utilized in order to demonstrate the trends in the field of infographics. The trend lines can be beneficial to researchers, as they facilitate comprehension of the field by presenting the year in which the research was conducted, the area of interest, the citations and the acknowledged communication.

\section{RESULT}

\subsection{Document types}

As Figure 2 below illustrates, the main papers published in different sources related to infographics throughout 2006-2016 were documents $(n=93,57.8 \%)$, and conference papers $(n=68,42.2 \%)$.

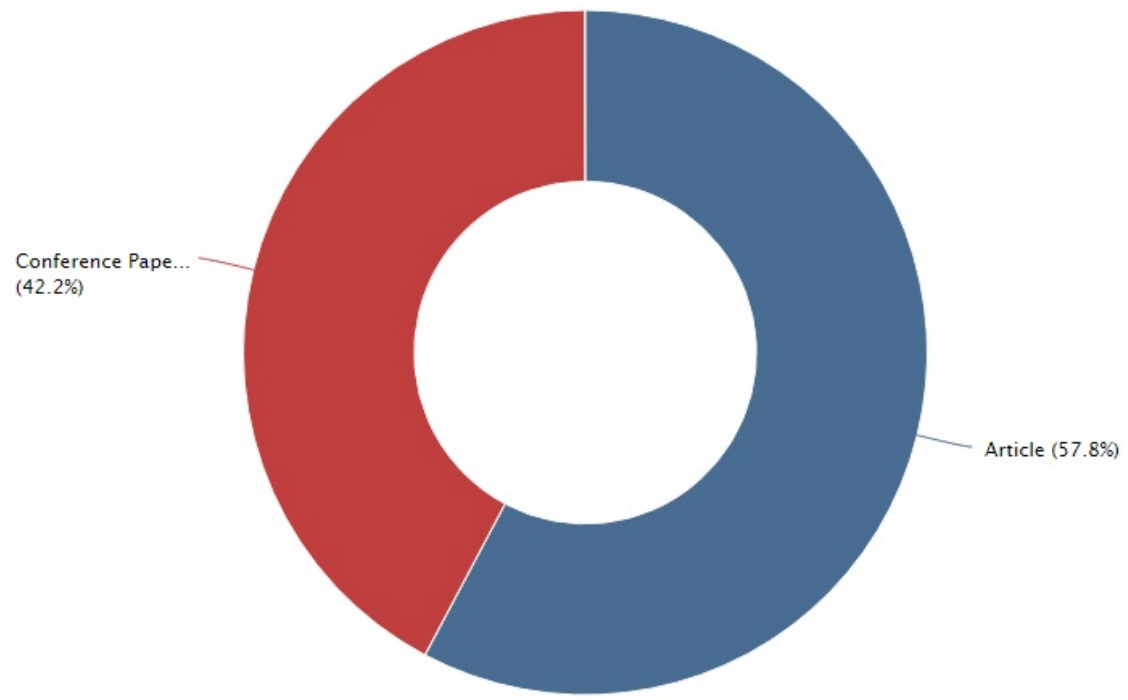

Figure 2: Types of published documents 


\subsection{Document's language}

The most repeatedly used language was English in the published works on infographics throughout 2006$2016(\mathrm{n}=146,90.6 \%)$. Eleven papers were published in Spanish, one paper in German, one paper in Arabic, one document in Korean, one paper in Portuguese, and one paper was in Catalan.

\subsection{Publication year}

Throughout 2006-2016, the numbers of papers on the subject of infographics have shown a yearly increase, from 1 paper in 2006 to 12 papers in 2012. The years that contained the lowest number of publications were 2006, 2007, and $2008(\mathrm{n}=1)$. However, 2012 was the year with the highest number of publications $(n=12)$. Afterward, the publication rate has been increased dramatically to 41 compare to the earlier years. In terms of the total number of published papers, $138(85 \%)$ have been published since 2013.

\subsection{The authors of document}

A total of 385 authors published 161 documents on infographics in the Scopus citation database. Authors who published more than one paper include Parmar, A., Akkoyunlu, B., Albers, M.J., Böschen, F., Carberry, Carberry, S., Cavanaugh, T., Chulkov, V., and Dick, M.. Furthermore, 281 authors wrote or cowrote one paper; therefore, it is observed that the majority of studies on infographics were co-authored.

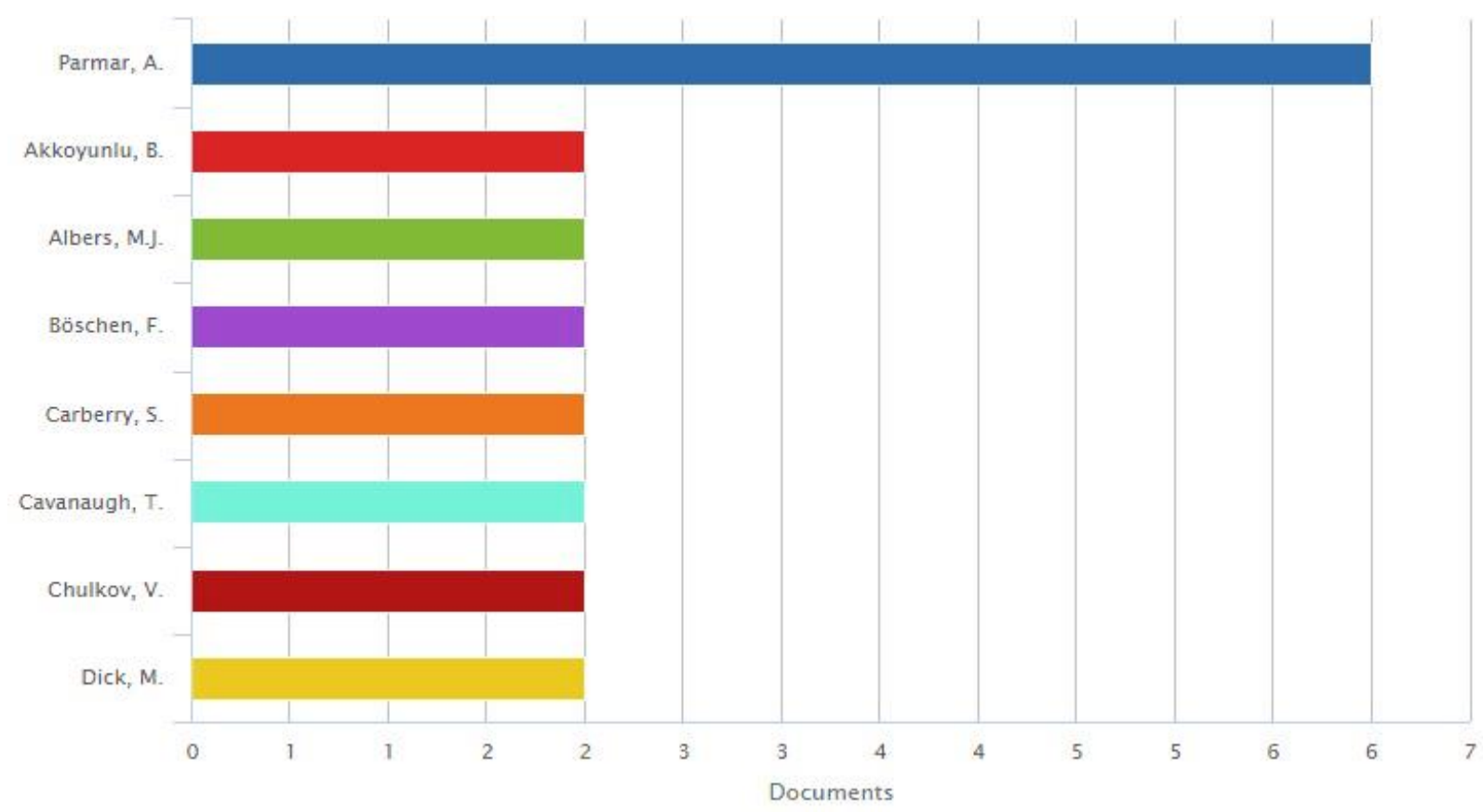

Figure 3: Authors of published documents

\subsection{The author's country}

Approximately $50 \%,(n=87)$ of the papers were published in five principal countries. The rest of the published papers $(23 \%)$ were from 35 other countries. One third of the authors $(n=54,31 \%)$ conducted their research in the United States, 30\% $(n=52)$ while documents were published in Spain and South Korea, $7 \%$ in the United Kingdom and Brazil and the remained were published in other countries. 


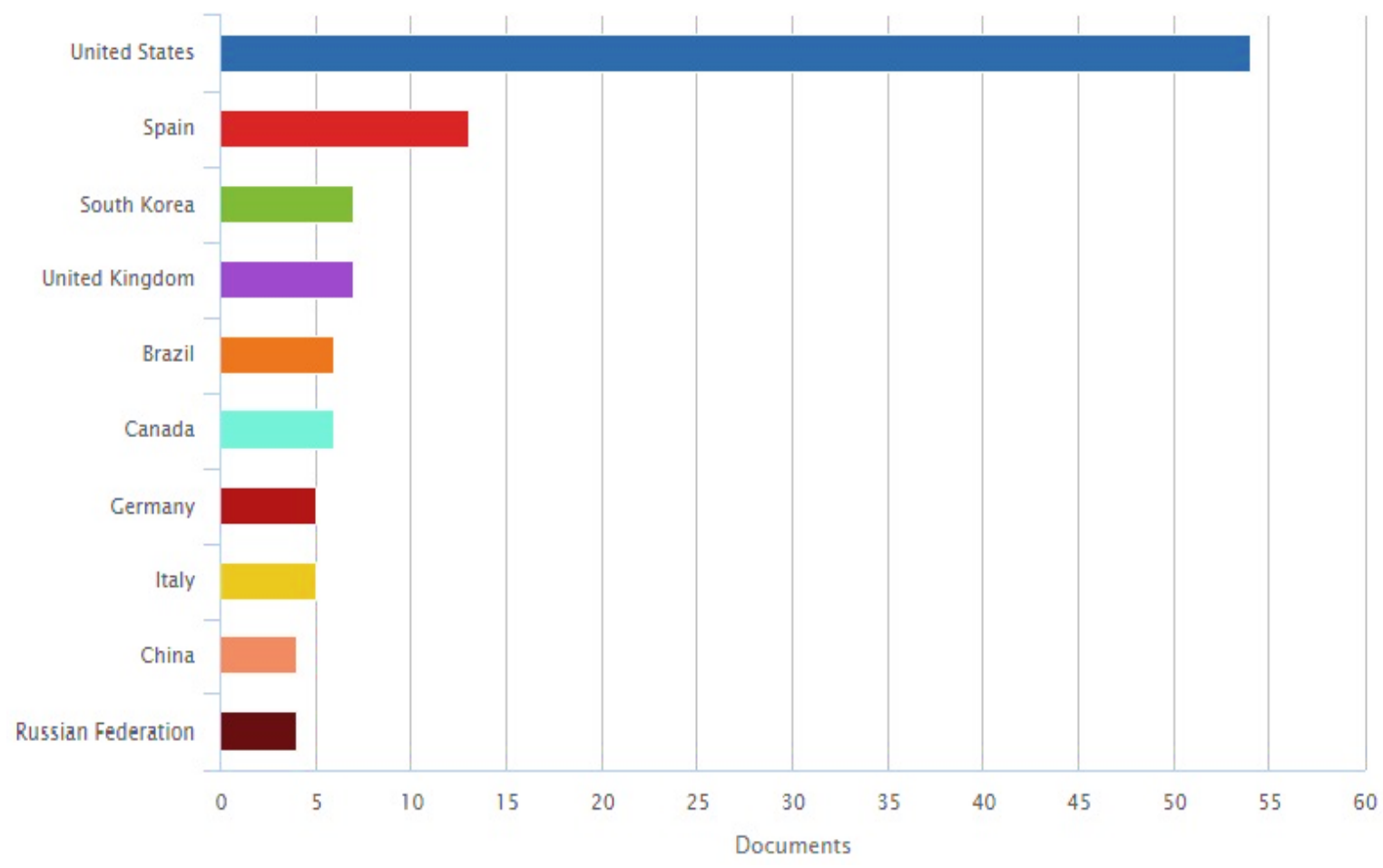

Figure 4: Countries of published documents

\subsection{Yearly Citation}

In order to specify the impact and quality of the published documents on infographics, documents were analyzed by yearly citation analysis in the Scopus database (February 2017). The yearly citation option related to infographics is illustrated in Figure 4.

The sources of citation by year on infographics contain a total of 229 papers that were cited throughout 2006-2016. However, the least number of citations was $(n=0)$ in 2006, 2007 and 2008. Afterward, the number of citation increased gradually and rose to the highest level of citations in $2016(\mathrm{n}=100)$. The reason for this is that infographics have become more popular in recent years; hence, most of the educational organizations, such as universities, colleges, and schools, are trying to incorporate this method of teaching in order to improve the learning skills in students. 
The Turkish Online Journal of Design, Art and Communication - TOJDAC October 2017 Volume 7 Issue 4

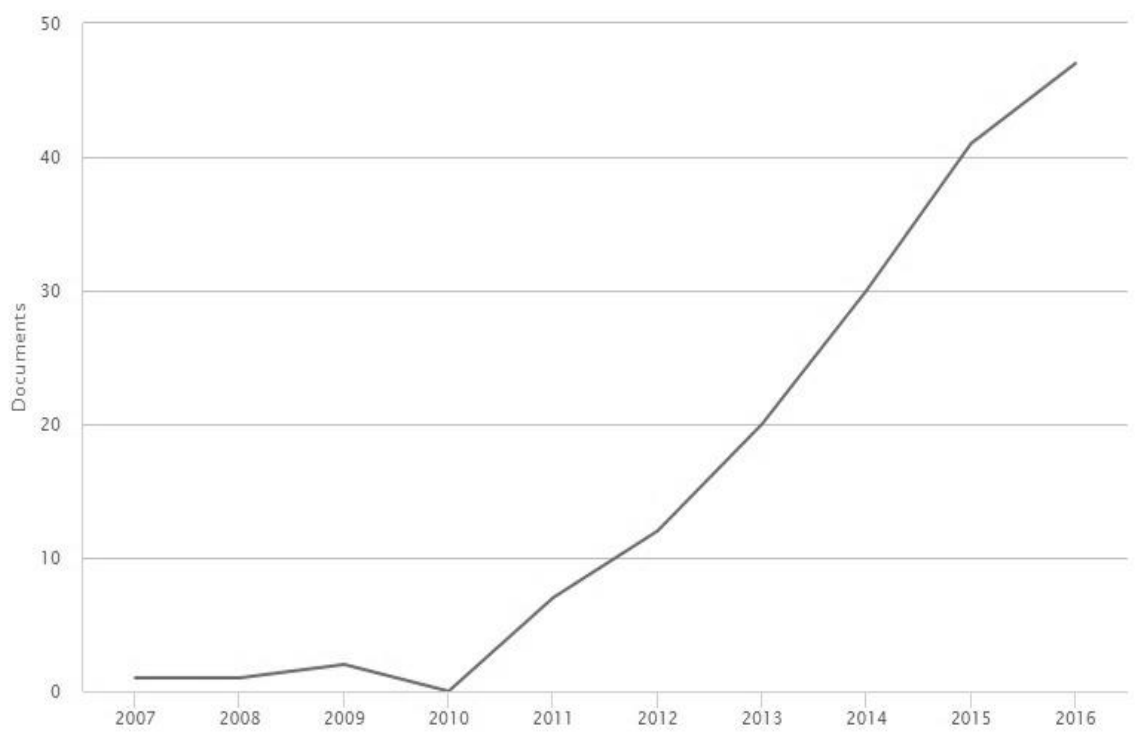

Figure 5: Published documents citation based on the year

\subsection{Most frequently cited papers analysis}

The papers that received more citations are recognized better by other scientists based on their research areas and fields and also because they provide more fundamental information about the related field for future research (Shih et al, 2008). Therefore, according to the citation numbers of the first five documents on infographics in the Scopus citation database, the highest citations were selected accordingly.

The most cited documents in infographics were related to the research category of 'observation' (Borkin et al, 2013; $\mathrm{n}=54$ ), focusing on how visualized information can be effectively designed and how data visualization could improve memorization. The second research document that obtained the most citations was "Influence of the mode of graphical representation on the perception of product aesthetic and emotional features" (Ramírez et al., 2008; $n=29$ ), which concentrates on the influence of infographic representation on learning.

The third paper that gained the most citations (Elzen et al, 2014; $n=22$ ) was predominantly focused on multivariate network exploration and presentations by non-expert users using the infographics teaching method.

The fourth most frequently cited document was titled "A system for understanding imaged infographics and its applications" (Huang \& Tan, 2007; n=16), which focused mainly on understanding the semantic information of infographics in documents and its applications. Finally, the least frequently cited document was about "Infovis and statistical graphics: Different goals, different looks" (Gelman \& Unwin, 2013; $\mathrm{n}=13$ ), which focused on graphical displays in statistical practice. 
The Turkish Online Journal of Design, Art and Communication - TOJDAC October 2017 Volume 7 Issue 4

\begin{tabular}{|c|c|c|c|c|c|}
\hline $\begin{array}{c}\text { Ran } \\
\mathbf{k}\end{array}$ & Study & Author(s) & $\begin{array}{l}\text { Publicat } \\
\text { ion year }\end{array}$ & $\begin{array}{c}\text { Research } \\
\text { Design }\end{array}$ & $\begin{array}{c}\text { Total } \\
\text { Citatio } \\
\mathbf{n}\end{array}$ \\
\hline 1 & $\begin{array}{l}\text { What makes a } \\
\text { visualization memorable }\end{array}$ & $\begin{array}{l}\text { Borkin, M.A.a, Vo, } \\
\text { A.A.a, Bylinskii, } \\
\text { Z.b, Isola, } \\
\text { P.c, Sunkavalli, } \\
\text { S.a, }, \text { Oliva, A.b and } \\
\text { Pfister, H.a }\end{array}$ & 2013 & Developmental & 54 \\
\hline 2 & $\begin{array}{l}\text { Influence of the mode of } \\
\text { graphical representation } \\
\text { on the perception of } \\
\text { product aesthetic and } \\
\text { emotional features: An } \\
\text { exploratory study }\end{array}$ & $\begin{array}{l}\text { Artacho-Ramírez, } \\
\text { M.A., Diego-Mas, } \\
\text { l.A., Alcaide- } \\
\text { Marzal, J. }\end{array}$ & 2008 & Developmental & 29 \\
\hline 3 & $\begin{array}{l}\text { Multivariate network } \\
\text { exploration and } \\
\text { presentation: From detail } \\
\text { to overview via selections } \\
\text { and agaregations }\end{array}$ & $\begin{array}{l}\text { Van Den Elzen, } \\
\frac{\text { S.ab }}{\text { L.J.a }}\end{array}$ & 2014 & Developmental & 22 \\
\hline 4 & $\begin{array}{l}\text { and aggregations } \\
\text { A system for } \\
\text { understanding imaged } \\
\text { infographics and its } \\
\text { applications }\end{array}$ & $\begin{array}{l}\text { Huang, W. }, \text { Tan, } \\
\text { C.L. }\end{array}$ & 2007 & Developmental & 16 \\
\hline 5 & $\begin{array}{l}\text { Infovis and statistical } \\
\text { graphics: Different goals, } \\
\text { different looks }\end{array}$ & $\begin{array}{l}\text { Gelman, A., Unwin, } \\
\underline{\text { A. }}\end{array}$ & 2013 & Developmental & 13 \\
\hline
\end{tabular}

Table1: The most cited documents in the Scopus citation database

\section{DISCUSSION}

In this study, the researchers have analyzed papers on infographics that were published in different journals from 2006 to 2016. The study was conducted by searching the Scopus database. Citation analysis in the study showed that 161 papers published in the Scopus database were related infographics. More than half were articles $(n=93,57.8 \%)$, and the rest were conference papers $(n=68,42.2 \%)$. English $(n=146$, $90.6 \%$ ) was the language mostly used in the published works about infographics.

Nevertheless, during the last few years, educational journals (BiD, Calidoscopio, Transactions of the Korean Institute of Electrical Engineers, Revista Latina de Comunicacion Social) have published papers not only in English but also in other languages, such as Spanish, Catalan, Korean, Portuguese, etc. Hence, as a consequence, there has been an increase in the number of papers on infographics published in diverse languages.

Furthermore, the numbers of papers related to infographics have shown yearly growth from 1 paper in 2006 to 12 papers in 2012. However, 2012 was the year with the maximum number of publication, therefore the publication rate has been increased dramatically to 41 compare to the earlier years. In terms

Submit Date: 13.06.2017, Acceptance Date: 16.09.2017, DOI NO: 10.7456/10704100/011 
of the total number of published papers, $138(85 \%)$ have been published since 2013. The reason for this is that infographics have recently become more popular; hence most educational organizations, such as universities, colleges, and schools, are trying to use this method of teaching in order to improve the students' learning skills.

Resultantly, scientists now have more access to papers and ICT developments have improve the field of infographics. Additionally, during the last few years, technology has advanced exponentially in the areas of computing, applications, and social networks. These technologies are represented by many applications, including Facebook, Twitter, Instagram, Google +, Myspace, YouTube, along with the second collaborative services generation which is called Web2.0. These services provide more dynamic interaction and participation in the online environment which, combined with Web2.0 technology, has initiated standard relation tools in private communication (O’Dell, 2009).

The majority of of published papers on infographics were co-authored. The same outcome was determined by scientists such as Uzunboylu and Ozcinar (2009) and Kirby, Hoadley and Carr-Chellman (2005). These scientists found that nearly $70 \%$ of the computer-assisted language learning and instructional system design and learning science papers they investigated had been co-authored.

However, Latchem (2006), in the BJET (British Journal of Educational Technology) and Misra (1997), in the American Journal of Distance Education found that $56 \%$ and $53.75 \%$ of the studies in the respective journals had been co-authored.

Hence, based on these results, it can be observed that there is a trend in documents on infographics in which the outcomes are based on collaborative work on the part of scientists.

In order to specify the impact and quality of the published documents on infographics, documents were analyzed by citation analysis by year in the Scopus citation database (February 2017). The number of published document citations was 229 in total during the period 2006-2016. However, there were $(n=0)$ citations during the period between 2006 and 2008. Afterward, the number of citations increased gradually until the highest level of citations was reached in $2016(n=100)$. The explanation for this is that scientists now have more convenient access to research documents. Hence, the expectation is that the number of citations for documents concerning infographics will rise on an annual basis.

However, the essence of this research is expressive; the aim is that the outcome of this study will be beneficial for educators and scientists in the field of infographics. Furthermore, this citation analysis approach is also of significant benefit for new generations of academics who choose to conduct research (Tsai \&Wen, 2005).

This approach to analysis can assist them when specifying modern study topics, trends, and methods as well as in comprehending the effects and the effectors in the related subjects (Gall et al, 2004). Moreover, having knowledge of the trends in recent studies can assist policy-makers in the related area when formulating future plans. The papers specified in the proposed research are considered as significant advances in infographics as well as other fields.

\section{RECOMMENDATIONS}

Although the current research employs an expressive method in order to specify the details of infographics papers, some criteria should be mentioned (Hoffman \& Holbrook, 1993). For instance, the citation analysis approach does not address why or how a particular study has been cited (Everett \& Pecotich, 1993). Additionally, the impact of infographics on a given paper cannot be measured in this way. 
The Turkish Online Journal of Design, Art and Communication - TOJDAC October 2017 Volume 7 Issue 4

Nevertheless, although the infographic scientists could be utilizing the information from a research in practice; this would not necessarily result in the paper's citation.

However, the citation analysis approach could be considered as one of the objective approaches when evaluating a paper, it can have some disadvantages, such as gratuitous citation, self-citation, and negative citation (Shih et al., 2008). Hence, it is recommended that a mixture of citation analysis and other approaches should be utilized in future studies about infographic in order to achieve better outcomes and similar research should be repeated every five years.

\section{REFERENCES}

Allahverdiyev, M. \& Yucesoy, Y. (2017). Development stages and types of glass art from past to present. Ponte 73(4), 224-238.

Angling, G. J. \& Towers, R. L. (1992). Reference citations in selected instructional design and technology journals, 1985-1990. Educational Technology Research and Development, 40, 1, 189-194.

Artacho-Ramírez, M.A. , Diego-Mas, J.A., Alcaide-Marzal, J. (2008). Influence of the mode of graphical representation on the perception of product aesthetic and emotional features: An exploratory study. International Journal of Industrial Ergonomics. Vol.38, Issue 11-12, pp 942-952

Aylward, B. S., Roberts, M. C., Colombo, J. \& Steele, R. G. (2008). Identifying the classics: an examination of articles published in the Journal of Pediatric Psychology from 1976-2006. Journal of Pediatric Psychology, 33, 6, 576-589.

Bagriyanik, S. \& Karahoca, A. (2016). Big data in software engineering: A systematic literature review.

Global Journal of Information Technology: Emerging Technologies 6(1), 107-116. doi: https://doi.org/10.18844/gjit.v6i1.397

Beuker, T. , Boerstra, A. (2012). Infographics used to communicate indoor climate investigation results. 10th International Conference on Healthy Buildings. Brisbane, QLD; Australia; 8 July Vol.2.pp16391642

Bicen, H. (2015). The Role of Social Learning Networks in Mobile Assisted Language Learning: Edmodo as a Case Study. Journal of Universal Computer Science, 21(10), 1297-1306.

Borkin, M.A.a, Vo, A.A.a, Bylinskii, Z.b, Isola, P.c, Sunkavalli, S.a, Oliva, A.b and Pfister, H.A. (2013). What makes a visualization memorable. IEEE Transactions on Visualization and Computer Graphics. Vol.19, Issue 12, no. 6634103, pp 2306-2315.

Brown, L. D. \& Gardner, J. C. (1985). Using citation analysis to assess the impact of journals and articles on contemporary accounting research (CAR). Journal of Accounting Research, 23, 1, Spring, 84-109.

Çetin, $S$. (2015). General trends in master and doctorate thesis in the area of computer education and instructional technologies in Turkey, International Journal of Innovative Research in Education.2(2), 5567. doi: https://doi.org/10.18844/ijire.v2i2.352

Claes, S., Vande Moere, A. (2013). Street infographics: Raising awareness of local issues through a situated urban visualization. 2nd ACM International Symposium on Pervasive Displays, Mountain View, CA; United States; Conference Proceedings, Chicago, IL, October 19-23, 2004.

Diodato, V. (1994). Dictionary of bibliometrics. Binghampton, NY: The Haworth Press, Inc.

Dhir, A., Gahwaji, N. M. \& Nyman, G. (2013). The role of the iPad in the hands of the learner. Journal of Universal Computer Science, 19(5), 706-727.

Ely, D. P. (2002). Trends in educational technology (5th ed.). Washington, D.C.: Association for Educational Communications and Technology.

Everett, J. E. \& Pecotich, A. (1993). Citation analysis mapping of journals in applied and clinical psychology. Journal of Applied Social Psychology, 23, 750-766.

Eybe, J. \& Schmidt, H.-J. (2001). Quality criteria and exemplary papers in chemistry education

Submit Date: 13.06.2017, Acceptance Date: 16.09.2017, DOI NO: 10.7456/10704100/011

Copyright (C) The Turkish Online Journal of Design, Art and Communication 
The Turkish Online Journal of Design, Art and Communication - TOJDAC October 2017 Volume 7 Issue 4

Gall, J., Ku, H. Y., Gurney, K., Tseng, H. W. \& Yeh, H. T. (2004). An analysis of citation patterns in ETR\&D, 1990-99. Association for Educational Communications \& Technology (AECT) 2004

Gall, J., Ku, H. Y., Gurney, K., Tseng, H. W. \& Yeh, H. T. (2004). An analysis of citation patterns in ETR\&D, 1990-99. Association for Educational Communications \& Technology (AECT) 2004 Conference Proceedings, Chicago, IL, October 19-23, 2004.

Garfield, E. (1955). Citation indexes for science: a new dimension in documentation through association of ideas. Science, 122, 108-111.

Gelman, A.,Unwin, A. (2013). Infovis and statistical graphics: Different goals, different looks. Journal of Computational and Graphical Statistics. Vol.22, pp 2-28

Hew, F. H. \& Kale, U. (2007). Past research in instructional technology: results of a content analysis of empirical studies published in three prominent instructional technology journals from the year 2000 through 2004. Journal of Educational Computing Research, 36, 3, 269-300.

Hoffman, D. L. \& Holbrook, M. B. (1993). The intellectual structure of consumer research: a bibliometric study of author co-citations in the first 15 years of the Journal of Consumer Research. Journal of Consumer Research, 19, 505-517.

Howard, G. S., Cole, D. A. \& Maxwell, S. E. (1987). Research productivity in psychology based on publication in the Journal of the American Psychological Association. American Psychologist, 42, 975986.

Huang, W. \& Tan, C.L. (2007). A system for understanding imaged infographics and its applications . DocEng'07: Proceedings of the 2007 ACM Symposium on Document Engineering Winnipeg, MB; Canada. pp. 9-18, Code 70911.

Hursen, C. \& Ozcinar, Z. (2008). Assesments of the studies on multiple intelligence theory through the content analyses method. Cypriot Journal of Educational Sciences, 1, 5, 1-15.

Kirby, J. A., Hoadley, C. M. \& Carr-Chellman, A. A. (2005). Instructional systems design and the learning sciences: a citation analysis. Educational Technology Research and Development, 53, 1, 37-48.

Klein, J. D. (1997). ETR\&D-development: an analysis of content and survey of future direction. Educational Technology Research and Development, 45, 3, 57-62.

Latchem, C. (2006). A content analysis of the British Journal of Educational Technology. British Journal of Educational Technology, 37, 4, 503-511.

Mahapatra, G. (2000). Bibliometric studies on Indian library \& information science literature (1st ed.). New Delhi: Crest Publishing House.

Maushak, N. J., Price, R. \&Wang, H. C. (2000). Identification and analysis of the leading journals in the field of educational technology: a guide for reading and writing about educational technology.

Mishra, S. (1997). A Critical Analysis of Periodical Literature in Distance Education. Indian Journal of Open Learning, 6, 1-2, 39-53.

Nederhof, A. (2006). Bibliometric monitoring of research performance in the social sciences and the humanities: a review. Scientometrics, 66, 1, 81-100.

O'Dell, C. (2009). Web 2.0 and knowledge management. Retrieved from: http://wiki.sla.org/download/attachments/11371006/APQC $+2008+$ Web $+2+$ and $+K M . p d f ?$ version $=1$

Ozdamli, F., \& Tavukcu, T. (2016). Determination of Secondary School Students' Attitudes towards Tablet PC Supported Education. Journal of Universal Computer Science, 22(1), 4-15.

Ramesh, L.S.R.C.V., \& Nagaraju, A.V.S.S. (2000). Citation analysis of the Indian Journal of Information, Library and Society. Indian Journal of Information, Library and Society, 13 (3-4), 171-179. Retrieved from: http://eprints.rclis.org/3140/

Reiser, R. A. \& Dempsey, J. V. (2007). Trends and issues in instructional design (2nd ed.). Upper Saddle River, NJ: Pearson Education, Inc. research. International Journal of Science Education, 23, 209-225.

Rousseau, R. (2008). Social information systems: Emerging technology and applications for searching the web effectively. Goh, D., \& Foo, S. (Eds.). Hershey (PA): Information Science Reference (IGI Global): $13,252-267$.

Submit Date: 13.06.2017, Acceptance Date: 16.09.2017, DOI NO: 10.7456/10704100/011 
Schwabish, J.A. (2012). Infographics at the Congressional Budget Office. IEEE Conference on Visual Analytics Science and Technology, WA; United States;

Shih, M., Feng, J. \& Tsai, C.-C. (2008). Research and trends in the field of e-learning from 2001 to 2005: a content analysis of cognitive studies in selected journals. Computers \& Education, 51, 2, 955-967.

Smith, M. C., Locke, S. G., Boisse, S. J., Gallagher, P. A., Krengel, L. E. \& Kuczek, J. E. (1998). Productivity of educational psychologists in educational psychology journals, 1991-1996. Contemporary Educational Psychology, 23, 173-181.

Tocque, K., Kennedy, L.C. (2013). Health \& wellness: Can infographics promote behaviour change? Proceedings of the 5th International Conference on Internet Technologies and Applications. Glyndwr University Wrexham, North Wales; United Kingdom;

Tsai, C. C. \& Wen, L. M. C. (2005). Research and trends in science education from 1998 to 2002: a content analysis of publication in selected journals. International Journal of Science Education, 27, 3-14.

Tuncali, E. (2016). The Infographics which are designed for environmental issues, Global Journal on Humanities \& Social Sciences. [Online]. 03, pp 14-19. doi: https://doi.org/10.18844/gjhss.v2i1.272

Uzunboylu, H. \& Ozcinar, Z. (2009). Research and trends in computer-assisted language learning during 1990-2008: results of a citation analysis. Egitim Arastirmalari-Eurasian Journal of Educational Research, 34, 133-150.

Uzunboylu, H., \& Karagozlu, D. (2015). Flipped classroom: A review of recent literature. World Journal on Educational Technology. 7(2), 142-147. doi: http://dx.doi.org/10.18844/wjet.v7i2.46

Van Den Elzen, S.ab, Van Wijk, J.J.a (2014). Multivariate network exploration and presentation: From detail to overview via selections and aggregations. IEEE Transactions on Visualization and Computer Graphics. Vol.20, Issue: 12, no.6875972, pp. 2310-2319. 